\title{
Imprinted genes and hypothalamic function
}

\author{
Elena Ivanova ${ }^{1}$ and Gavin Kelsey ${ }^{1,2}$ \\ ${ }^{1}$ Epigenetics Programme, The Babraham Institute, Cambridge CB22 3AT, UK \\ ${ }^{2}$ Centre for Trophoblast Research, University of Cambridge, Cambridge CB2 3EG, UK \\ (Correspondence should be addressed to G Kelsey at Epigenetics Programme, The Babraham Institute; Email: gavin.kelsey@babraham.ac.uk)
}

\begin{abstract}
Genomic imprinting is an important and enigmatic form of gene regulation in mammals in which one copy of a gene is silenced in a manner determined by its parental history. Imprinted genes range from those with constitutive monoallelic silencing to those, typically more remote from imprinting control regions, that display developmentally regulated, tissuespecific or partial monoallelic expression. This diversity may make these genes, and the processes they control, more or less sensitive to factors that modify or disrupt epigenetic marks. Imprinted genes have important functions in development and physiology, including major endocrine/neuroendocrine axes. Owing to is central role in coordinating growth, metabolism and reproduction, as well as evidence from genetic and knockout studies, the hypothalamus may be a focus for imprinted gene action. Are there unifying principles that explain why a gene should be imprinted? Conflict between parental genomes over limiting maternal resources, but also co-adaptation between mothers and offspring, have been invoked to explain the evolution of imprinting. Recent reports suggest there may be many more genes imprinted in the hypothalamus than hitherto expected, and it will be important for these new candidates to be validated and to determine whether they conform to current notions of how imprinting is regulated. In fully evaluating the role of imprinted genes in the hypothalamus, much work needs to be done to identify the specific neuronal populations in which particular genes are expressed, establish whether there are pathways in common and whether imprinted genes are involved in long-term programming of hypothalamic functions.
\end{abstract}

Journal of Molecular Endocrinology (2011) 47, R67-R74

\section{Introduction}

Imprinted genes in mammals pose an exception to Mendelian inheritance, because one of their two copies (alleles) has been silenced in a manner predetermined by the sex of the parent transmitting the allele. There are imprinted genes for which the allele from the mother is silent and imprinted genes for which the father's allele is silent. Imprinting is a classic epigenetic phenomenon: the distinct activity states of the two alleles represent a memory of an earlier decision and can coexist throughout the lifetime of the individual, but are reversible, as imprinting is reset during passage through the germline (Ferguson-Smith \& Surani 2001, Arnaud 2010). Until recently, 100 imprinted genes had been identified in mouse and somewhat fewer in human (www.geneimprint.com), with imprinting of many conserved between the two species (Morison et al. 2005). A recent report, however, suggests that the figure may be substantially higher (Gregg et al. 2010a). Imprinted genes are recognised as playing important roles in foetal and placental development, growth of the foetus, peri- and postnatal physiology and in certain behaviours (Charalambous et al. 2007). Whether all these processes have been primarily targeted for control by imprinting or are epiphenomena the outcome is the same: having only one functional copy of a gene means that there is no backup to safeguard against mutations. Accordingly, inactivating mutations in imprinted genes or other defects that eliminate the active copy are responsible for a number of genetic syndromes (Butler 2009). Disease can also arise from 'loss of imprinting', when the normally repressed copy of an imprinted gene becomes reactivated leading to overexpression. Given these potential hazards, there must be an evolutionary benefit to imprinting, especially since many imprinted genes are shared between human and mouse, and imprinting of the insulin-like growth factor 2 (Igf2) and $H 19$ genes can be traced back to marsupials (Smits et al. 2008).

Silencing one allele of an imprinted gene is achieved by mechanisms that involve DNA methylation, repressive histone modifications and the actions of 
non-coding RNAs, and a great deal of progress has been made in understanding the processes that lead to the establishment and maintenance of imprinting (Weaver et al. 2009). Fundamental to imprinting is the establishment of differences in DNA methylation between male and female gametes at imprinting control regions (ICRs), and these primary imprint marks persist throughout the lifetime of an individual and are only erased and reset in the germline. Most imprinted genes occur in clusters that span several hundred kilobases and monoallelic expression of all genes in a cluster is determined in cis by a single ICR. Whilst the primary epigenetic marks at ICRs are maintained during the lifetime, not all imprinted genes are expressed monoallelically throughout life. The human IGF2 gene is expressed predominantly from the paternal allele in the foetus and placenta, but from both alleles equally in the liver after birth (Vu \& Hoffman 1994). GNAS, which encodes the stimulatory $G$ protein $\alpha$ subunit Gs $\alpha$, exhibits paternal allele silencing in a limited set of tissues, including the pituitary, thyroid and hypothalamus (Hayward et al. 2001, Mantovani et al. 2002, Liu et al. 2003, Germain-Lee et al. 2005, Chen et al. 2010). This may suggest that imprinted expression for a widely expressed gene with pleiotropic effects (as a common mediator of $\mathrm{G}$ protein-coupled receptor signalling) has been selected only for a subset of the functions it serves. Stage- or tissue-specific imprinting might be the consequence of the fact that most imprinted genes in clusters are not directly repressed by the monoallelic DNA methylation present at ICRs, but rely on mechanisms such as silencing by non-coding RNAs that originate from ICRs (Weaver et al. 2009). Such indirect mechanisms may also allow a degree of plasticity in imprinting, but the possibility that there is interindividual variation in imprinting deserves further investigation (Turan et al. 2010). It is important to stress that whether or not monoallelic expression is maintained, the primary imprint marks at ICRs remain in place.

\section{The hypothalamus as a hotspot of imprinted gene expression}

The findings that mouse knockouts for several imprinted genes have disturbed metabolic control highlights the hypothalamus as a potential major site for the action of imprinted genes (Charalambous et al. 2007, Frontera et al. 2008). The hypothalamus is a key regulator of many endocrine functions and is involved in the regulation of energy balance through its influence on food intake, metabolic rate and body temperature by the action of a dozen small nuclei. It has well-defined circuits between the nuclei that allow integration and fine-tuning of the systems responsible for homeostasis and adaptation to environmental change. Developmental studies using aggregation chimaeras in mice, in which parthenogenetic (PG) or androgenetic cells (AG) were combined with normally fertilised embryos, provided evidence for a role of imprinted genes in brain development, including the hypothalamus. PG embryos are produced by activation of unfertilised oocytes and contain no paternal genetic contribution; AG embryos by pronuclear transplantation in one-cell embryos and contain two paternal genomes. AG and PG cells are generally at a disadvantage during embryonic development, but in the brain AG cells become restricted to the hypothalamus, whereas PG cells are excluded and are found predominantly in the cortex (Allen et al. 1995, Keverne et al. 1996). This work graphically illustrated that paternally and maternally expressed imprinted genes might have distinct impacts on brain development and function, suggesting, for example, that paternally expressed gene function may predominate in regions associated with primary motivated behaviours (Keverne et al. 1996). A number of imprinted genes are now known to be expressed in hypothalamic nuclei and could be involved in establishing hypothalamic neuroarchitecture and neural circuits. In an extensive survey of imprinted gene expression in mouse brain, it was found that certain regions, in particular the hypothalamus, express a higher proportion of the known imprinted genes (Gregg et al. 2010a). Neural systems associated with feeding and metabolism, and motivational behaviours emerged as 'hotspots' for imprinted genes.

\section{Imprinted gene disorders with a neuroendocrine involvement}

The involvement of imprinted genes in neuroendocrine and endocrine function was first suggested by the discovery of the imprinted basis of disorders such as the Prader-Willi syndrome (PWS) and Albright hereditary osteodystrophy (AHO). PWS is a complex neuroendocrine and behavioural disorder that presents in infants with hypotonia and feeding difficulties, followed by hyperphagia and undiscerning eating, development of morbid obesity, hypogonadism and cognitive delays (Cassidy \& Driscoll 2009). Patients present with low levels of testosterone, gonadotropins, GH and IGF1 (Miller et al. 2008); they are also deficient in the anorectic peptide YY and have elevated levels of gut peptides obestatin and ghrelin, but normal thyroid and adrenal function, suggesting primary hypothalamic rather than endocrine dysfunction. There are reports of hypothalamic abnormalities in patients, including reduced numbers of oxytocin-producing neurons (Swaab 1997). The PWS region on chromosome $15 q 11-q 13$ is one of the most complex imprinted 
domains and comprises numerous paternally expressed imprinted genes, suggesting that full-blown PWS is best considered a contiguous gene syndrome. The region also encodes multiple small nucleolar RNAs (snoRNA), particularly of the $\mathrm{C} / \mathrm{D}$ box class, which are involved in RNA processing, and recent genetic analysis in patients (Sahoo et al. 2008, de Smith et al. 2009) and knockout studies in mice (Ding et al. 2008, 2010) implicate disruption of specific snoRNAs as a major factor in PWS.

AHO, an autosomal dominant disorder caused by inactivating mutations in GNAS, represents the classical endocrine imprinted disorder. Characteristics include short stature, brachymetacarpia, subcutaneous ossification and developmental delay, but a remarkable feature is that presentation depends on parental origin (Davies \& Hughes 1993, Wilson et al. 1994). When transmitted from mothers, AHO is accompanied by the hormone resistance syndrome pseudohypoparathyroidism type 1a (PHP1a), characterised by development of end-organ resistance to a subset of hormones - parathyroid hormone, GHRH, TSH and gonadotropins - which depend on Gs $\alpha$-coupled receptors (Weinstein 1998). AHO may be explained by generalised haploinsufficiency of GNAS; PHPla represents the additional consequences of tissuespecific imprinting of $G N A S$ - the relative silencing of the paternal allele - such that in some tissues Gs $\alpha$ function is effectively absent or severely reduced when the maternal allele carries a mutation. The imprinted aetiology of PHPla is underlined by the related disorder PHP1b, in which much of the spectrum of hormone resistance typical of PHPla occurs in the absence of the physical features of AHO (Kelsey 2010). PHP1b is caused by epigenetic defects of GNAS imprinting rather than inactivating mutations (Liu et al. 2000, Bastepe et al. 2001). PHP1a patients also develop obesity (Long et al. 2007) but, since GNAS expression is not imprinted in adult adipose tissue (Mantovani et al. 2004, Chen et al. 2010), Gs $\alpha$ function in adipocytes is not a major contributor to this metabolic phenotype, despite the key role of Gs $\alpha$ in regulating lipid mobilisation. Instead, evidence from tissue-specific ablation of Gnas in mouse implicates imprinted expression in the hypothalamus as the cause (Chen et al. 2009).

\section{Studies of imprinted gene function in the hypothalamus}

For a number of imprinted genes, knockouts have revealed defects in hypothalamic development and function (Table 1). Amongst imprinted genes in the PWS domain in 15q11-q13, evidence from mouse studies indicates that several are expressed in the hypothalamus and their deficiency may contribute to some aspects of the complex PWS phenotype. Magel2 encodes a putative transcriptional regulator expressed predominately in the brain and especially during late developmental stages in the hypothalamus (Kozlov et al. 2007). Magel2-deficient mice exhibit neonatal growth retardation, altered metabolism and increased adiposity, despite a reduction in food intake (Bischof et al. 2007, Kozlov et al. 2007). They have reduced numbers of orexin neurons and orexin levels in the lateral hypothalamus, suggesting a role for Magel2 in neuronal development. There is accumulation of oxytocin intermediates in hypothalamus of neonates and injection of oxytocin rescues the feeding impairments and lethality (Schaller et al. 2010). Ndn encodes necdin, a potent post-mitotic growth suppressor and anti-apoptotic factor predominately expressed in differentiated neurons (Muscatelli et al. 2000). Necdin is highly expressed during development of the nervous system and interacts with neurotrophic receptors. Several knockout models of $N d n$ have been reported with different phenotypic outcomes ranging from early postnatal lethality owing to respiratory distress to normal viability (Gérard et al. 1999, Muscatelli et al. 2000, Kuwako et al. 2005). Ndn knockout mice variously demonstrate hypothalamic changes, including reduced numbers of oxytocin- and LHRH neurons (Muscatelli et al. 2000), more generalised defects in neuronal differentiation (Kuwako et al. 2005, Kuwajima et al. 2006) and abnormally high levels of serotonin in the medulla (Zanella et al. 2008). Necdin is also implicated in axonal outgrowth, routing and fasciculation, thereby possibly participating in establishment of neuroendocrine circuits (Lee et al. 2005).

Besides genes associated with PWS, several other imprinted genes are implicated in regulating hypothalamic functions. The paternally expressed gene for neuronatin (Nnat) is expressed abundantly in various hypothalamic nuclei. Expression is downregulated after fasting and in genetic models of obesity $(o b / o b$ mice), and is responsive to leptin administration, suggesting an involvement in regulating energy homeostasis. No knockout of Nnat has been reported, but in humans single nucleotide polymorphisms in NNAT are associated with severe childhood and adult obesity (Vrang et al. 2010). Of additional imprinted genes with hypothalamic functions, Gnas and Peg3 are dealt with in detail below. Together, these observations suggest that a number of imprinted genes expressed in the hypothalamus from early developmental stages participate in establishing neuronal circuits responsible for fine-tuning and coordinating the system to anticipate appropriate responses to the environment. 
Table 1 Imprinted gene knockouts in the mouse demonstrating hypothalamic effects

\begin{tabular}{|c|c|c|c|c|}
\hline $\begin{array}{l}\text { Imprinted } \\
\text { gene }\end{array}$ & Expressed allele & $\begin{array}{l}\text { Function of the } \\
\text { gene product }\end{array}$ & Knockout phenotype & References \\
\hline \multirow[t]{2}{*}{ Magel2 } & Paternal & $\begin{array}{l}\text { Putative transcription } \\
\text { factor }\end{array}$ & $\begin{array}{l}\text { Neonatal growth retardation, excessive } \\
\text { post-weaning weight gain, increased } \\
\text { adiposity and altered metabolism }\end{array}$ & Bischof et al. (2007) \\
\hline & & & $\begin{array}{l}\text { Reduced amplitude of activity and increased } \\
\text { daytime activity, reduced food intake, } \\
\text { orexin levels and number of orexin-positive } \\
\text { neurons }\end{array}$ & Kozlov et al. (2007) \\
\hline \multirow[t]{3}{*}{ Ndn } & Paternal & Post-mitotic growth & Early postnatal lethality & Gérard et al. (1999) \\
\hline & & suppressor & $\begin{array}{l}\text { Neonatal lethality, reduction in oxytocin- and } \\
\text { LHRH-producing neurons in hypothalamus }\end{array}$ & Muscatelli et al. (2000) \\
\hline & & & $\begin{array}{l}\text { Impaired neuronal development and } \\
\text { differentiation }\end{array}$ & $\begin{array}{l}\text { Kuwako et al. (2005) and } \\
\text { Kuwajima et al. (2006) }\end{array}$ \\
\hline \multirow[t]{5}{*}{ Gnas } & Maternal allele-specific & Stimulatory G protein & Constitutive knockouts (maternal transmission) & \\
\hline & expression limited to & $\alpha$ subunit & Higher birth weight, TSH and PTH resistance & Germain-Lee et al. (2005) \\
\hline & specific tissues (PVN) & & $\begin{array}{l}\text { Reduced metabolic rate, energy expenditure } \\
\text { and locomotor activity, severe obesity, } \\
\text { insulin resistance and impaired } \\
\text { glucose tolerance }\end{array}$ & Chen et al. (2005) \\
\hline & & & Brain-specific knockout (maternal transmission) & \\
\hline & & & $\begin{array}{l}\text { Obesity, reduced metabolic rate, impaired } \\
\text { melanocortin response and insulin resistance }\end{array}$ & Chen et al. (2009) \\
\hline Gnasxl & Paternal & $\begin{array}{l}\text { Extra-large isoform } \\
\text { of stimulatory G } \\
\text { protein } \alpha \text { subunit }\end{array}$ & $\begin{array}{l}\text { Decreased adiposity and body weight, } \\
\text { elevated metabolic rate, improved glucose } \\
\text { tolerance and insulin sensitivity }\end{array}$ & Xie et al. (2006) \\
\hline \multirow[t]{2}{*}{ Peg3 } & Paternal & $\begin{array}{l}\text { Zinc finger } \\
\text { transcription factor }\end{array}$ & $\begin{array}{l}\text { Foetal growth retardation, maternal behaviour } \\
\text { impairment, altered neuropeptide balance } \\
\text { and reduction in oxytocin-positive neurons }\end{array}$ & Li et al. (1999) \\
\hline & & & $\begin{array}{l}\text { Growth retardation, lower core body } \\
\text { temperature, reduced metabolic rate, } \\
\text { increased adiposity, elevated leptin, leptin } \\
\text { resistance, altered hypothalamic } \\
\text { neuropeptide expression and later } \\
\text { onset of puberty }\end{array}$ & Curley et al. (2005) \\
\hline
\end{tabular}

\section{Reasons for imprinting in the hypothalamus}

Why should the hypothalamus be a hotspot for imprinted genes? A number of explanations for the evolution of imprinting in mammals have been advanced (as far as we know, amongst vertebrates genomic imprinting is restricted to placental mammals), the most pertinent to hypothalamic function appear to be 'conflict' and 'co-adaptation'. The 'conflict hypothesis' posits that the inequality in parental investment in placental mammals and opportunity for paternal genes to manipulate the amount of resources offspring obtain from mothers, together with the likelihood that these paternal genes are not related to paternal genes in future offspring from the same female, gives rise to different selective pressures on paternal and maternal genes in offspring. Paternal genes can be considered resource demanding, whilst maternal genes in offspring have an interest in conserving maternal resources for the future reproductive health of the mother (Moore \& Haig 1991). Most imprinted genes that influence foetal and early postnatal growth and development satisfy the predictions of conflict theory, but the theory has had less success in predicting the actions of imprinted genes in adults, and there seems to be no neat division between the effects of maternally and paternally expressed genes in processes such as metabolism (Haig 2004, Frontera et al. 2008).

The Gnas locus exemplifies the possibility of conflict because of the opposing effects of maternally and paternally expressed gene products. The canonical Gnas transcript encoding Gs $\alpha$ is expressed with a highly cell-type pattern of silencing of the paternal allele. But there is an isoform of Gs $\alpha$, called XL $\alpha$ s, that is produced exclusively by the paternal allele. The XLas-encoding transcript Gnasxl is determined by an alternative, upstream promoter, such that XL $\alpha$ s contains essentially all the functional domains of Gs $\alpha$, which are encoded by shared exons, but XL $\alpha$ s has a specific, large amino-terminal domain (Kehlenbach et al. 1994). 
XLas stimulates adenylyl cyclase in response to receptor activation in a similar manner to Gs $\alpha$ (Bastepe et al. 2002), although it may interact more avidly with the plasma membrane and be sensitive to lower ligand concentrations (Kaya et al. 2009). In some circumstances in vivo XL $\alpha$ s can replace Gs $\alpha$ (Liu et al. 2011). In contrast to similar biochemical properties, at a physiological level Gs $\alpha$ and XL $\alpha$ s appear to act in opposing pathways. This was intimated by the first gene knockout of Gnas, which targeted exon 2 common to both Gs $\alpha$ - and XL $\alpha$ sproducing transcripts. The exon 2 disruption causes severe phenotypes in heterozygotes but, remarkably, these differ according to whether the mutation is transmitted maternally or paternally (Yu et al. 1998). Mice lacking maternal Gs $\alpha$ expression are hypometabolic and become obese, with decreased activity and energy expenditure, on account of reduced activity of the sympathetic nervous system; mice with the paternal mutation are lean and hypermetabolic owing to increased sympathetic activity (Yu et al. 2000). Further analysis of mice with disruption specifically of Gs $\alpha$ (deletion of the Gs $\alpha$-specific exon 1) or of XLas attributes the maternal hypometabolic phenotype to lack of Gs $\alpha$ and the paternal hypermetabolic phenotype to lack of XLas (Chen et al. 2005, Xie et al. 2006). Recent work on a conditional knockout of Gs $\alpha$ establishes that the metabolic phenotypes are determined in the central nervous system (Chen et al. 2009): ablating Gs $\alpha$ in neurons reproduces the hypometabolic phenotype, but only in heterozygotes lacking Gs $\alpha$ from the maternal allele. The central melanocortin system is a major regulator of metabolic rate and the melanocortin- 4 receptor is Gs $\alpha$ coupled. Brain-specific maternal Gs $\alpha$ deficient mice have a blunted metabolic response to melanocortins even before the onset of obesity. In situ hybridisation revealed imprinted expression of Gs $\alpha$ in the hypothalamus, specifically in the paraventricular nucleus (PVN), whereas in other brain regions expression from both alleles is similar. Specific deletion of Gs $\alpha$ in the PVN will be required to show definitively that imprinted expression in this region is involved in regulating metabolic rate. In contrast to Gs $\alpha, \mathrm{XL} \alpha$ s has a far more restricted domain of expression, including the hypothalamus, and is strictly imprinted. The extent to which the lean, hypermetabolic phenotype of XL $\alpha$ Sdeficient mice has a basis in hypothalamic expression of $\mathrm{XL} \alpha \mathrm{s}$ is unclear, as the existing knockout is a constitutive deletion. However, XL $\alpha$ s is expressed predominantly within orexigenic neurons (E Ivanova, G Kelsey and M Frontera, unpublished observations), giving rise to the possibility that XLas may function as the major Gs $\alpha$ isoform in hypothalamic regions suppressing metabolic rate and is involved preferentially in transducing signals from receptors for energy preserving pathways. It will be important to investigate how the respective phenotypes are modified when Gs $\alpha$ and XLas deficiencies are combined to establish whether these oppositely imprinted gene products indeed have antagonistic functions compatible with the conflict theory.

An alternative hypothesis considers that imprinted expression can arise because of 'co-adaptation' of maternal and offspring traits in the interests of achieving optimal birth weight and fitness of offspring, to ensure not only that offspring extract optimal resources from females but that females are capable of optimal provisioning their young (Wolf \& Hager 2006). The paternally expressed gene $P \operatorname{Peg} 3$, which encodes a Krüppel-type zinc finger transcription factor involved in apoptotic pathways (Relaix et al. 1998, Kohda et al. 2001), is an exemplar of this concept. $P \operatorname{eg} 3$ is expressed from early embryogenesis (Kuroiwa et al. 1996); in the brain, it is prominent in the arcuate, ventromedial, dorsomedial, paraventricular and some other hypothalamic nuclei. Deficiency of $P e g 3$ results in foetal growth retardation ( $\mathrm{Li}$ et al. 1999). In adult Peg3 knockout mice the balance of feeding peptides is changed in the hypothalamus and sympathetic activity is decreased, as reflected in lower core body temperature and metabolic rate and increased adipose tissue mass (Curley et al. 2005). In addition, $P e g 3$ knockout mice have reduced numbers of oxytocin-positive neurons, and females exhibit impaired milk ejection and deficits in maternal care (Li et al. 1999). It is possible that Peg3 is essential for development of neuronal circuitry and establishment of normal hypothalamic function, not only for the metabolic needs of the individual, but also to prime the mother for successful pregnancy and to optimise postpartum mother:offspring interactions. In the view of co-adaptation, the expression domains of $P e g 3$ in the embryo and the mother work in concert: Peg3 helps shape development of the hypothalamus in utero at a time when, and in part because, it is also operating in the placenta to promote nutrient acquisition from the mother. The outcome is that offspring that have grown well and extracted optimal resources will be destined to be good mothers as well (Keverne 2009). With the focus on offspring:mother interactions, sexually dimorphic expression of $\mathrm{Peg} 3$ in the adult hypothalamus might be expected, but no information is available. At this point, it is difficult to conclude whether co-adaptation or conflict is the major driver for imprinted genes in the hypothalamus, and it may be that different selective pressures have driven the evolution of imprinting at different loci (Wolf \& Hager 2006).

\section{How many genes are imprinted in the hypothalamus?}

In the past 20 years, over 100 imprinted genes have been discovered in the mouse (www.geneimprint.com) and it is possible that most imprinted genes with major 
phenotypic effects (e.g. embryo growth and viability) have been accounted for (Cattanach \& Beechey 2004). However, it is likely that others exist, especially genes with temporally or cell-type restricted imprinting (Schulz et al. 2009), but these require more effort to locate. One promising approach is transcriptome sequencing, using next generation sequencing (mRNA-Seq), of tissues from hybrid mice (Babak et al. 2008, Gregg et al. 2010a,b). The principle is that mRNASeq at sufficient sequencing depth quantifies allelic expression on the basis of differences in read numbers of sequences containing parental allele variants, given appropriate statistical tests. Using reciprocal crosses (i.e. if one cross is between strain A female and strain B male, the reciprocal is strain $\mathrm{B}$ female with strain A male), skewed allele representation attributed to a parent-of-origin effect can be distinguished from expression bias owing to genetic difference between alleles. Moreover, the resolution of sequencing allows differential imprinting of alternative transcripts of the same gene to be discriminated. In studies reported by Gregg et al. (2010a), 256 new candidate imprinted genes (and additional non-coding transcripts) were identified in the adult mouse hypothalamus (preoptic area). Interestingly, there was a pronounced bias towards paternally expressed genes and rather little overlap with the smaller number of imprinted candidates identified in another brain area, the prefrontal cortex, recalling the preferential survival of AG cells in the hypothalamus in chimaera studies (Allen et al. 1995, Keverne et al. 1996). Extensive validation studies will need to be done to conclude how many candidates correspond to new imprinted genes, and the number displaying apparently partial allelic silencing may suggest a proportion of false positives, but the approach correctly scored the majority of known imprinted genes expressed in the brain, including cases of highly isoform-specific monoallelic expression, such as the Inpp 5 fgene. In addition to 'conventional imprinting', a substantial number of autosomal genes were identified that exhibited sex-specific biases in parental allele expression (Gregg et al. 2010b). In the adult hypothalamus, many more 'sex-specific imprinted genes' were predicted in females than males, possibly reflecting the sexually dimorphic nature of the hypothalamus and its involvement in the control of maternal and mating behaviours, and the influence of known imprinted genes on maternal behaviour (e.g. Peg3). Concerning the functions of the new candidates, gene ontology analysis identified cell adhesion as the most highly enriched process in the adult hypothalamus (which might be skewed by several protocadherin genes showing parent-of-origin effects) and metabolic processes for candidates in embryonic brain. Enrichment in cell adhesion molecules could support a role of imprinted genes in controlling neural architecture.

\section{Conclusions and perspectives}

It is clear from theoretical concepts and experimental observations of a handful of genes that the hypothalamus is an important site of action of imprinted genes, and disruption in normal hypothalamic expression may contribute to imprinted gene syndromes. It is too soon to evaluate the significance of the discovery of several hundred new imprinted gene candidates in the hypothalamus, including those with sex-limited imprinting, and comprehensive validation studies are required as well as investigating the basis of their monoallelic expression. We also need much more refined analysis, for instance, on the identity of neuronal subtypes expressing the various imprinted genes to be able to assess the extent to which imprinted genes function in common pathways. Systematic studies, such as transcriptome sequencing of defined neuronal subpopulations from hybrid mice, would be beneficial. Up to now, no imprinted gene has been ablated specifically in the hypothalamus, and this type of approach will be important to separate functions in the hypothalamus from possible confounds from other or earlier developmental effects of genes with pleiotropic functions. The extent to which imprinted genes are involved in developmental modelling of the hypothalamus needs further study, as well as the degree to which the epigenetic control of imprinted genes is responsive to extrinsic signals in a manner that may have lasting impacts on hypothalamus function.

\section{Declaration of interest}

The authors declare that there is no conflict of interest that could be perceived as prejudicing the impartiality of the research reported.

\section{Funding}

This work was supported by the Biotechnology and Biological Sciences Research and the Medical Research Council (grant number G0400155) of the United Kingdom.

\section{References}

Allen ND, Logan K, Lally G, Drage DJ, Norris ML \& Keverne EB 1995 Distribution of parthenogenetic cells in the mouse brain and their influence on brain development and behavior. PNAS 92 10782-10786. (doi:10.1073/pnas.92.23.10782)

Arnaud P 2010 Genomic imprinting in germ cells: imprints are under control. Reproduction 140 411-423. (doi:10.1530/REP-10-0173)

Babak T, Deveale B, Armour C, Raymond C, Cleary MA, van der Kooy D, Johnson JM \& Lim LP 2008 Global survey of genomic imprinting by transcriptome sequencing. Current Biology 18 1735-1741. (doi:10. 1016/j.cub.2008.09.044)

Bastepe M, Pincus JE, Sugimoto T, Tojo K, Kanatani M, Azuma Y, Kruse K, Rosenbloom AL, Koshiyama H \& Jüppner H 2001 Positional dissociation between the genetic mutation responsible for 
pseudohypoparathyroidism type $\mathrm{Ib}$ and the associated methylation defect at exon A/B: evidence for a long-range regulatory element within the imprinted GNAS1 locus. Human Molecular Genetics 10 1231-1241. (doi:10.1093/hmg/10.12.1231)

Bastepe M, Gunes Y, Perez-Villamil B, Hunzelman J, Weinstein LS \& Jüppner H 2002 Receptor-mediated adenylyl cyclase activation through XLalpha(s), the extra-large variant of the stimulatory G protein alpha-subunit. Molecular Endocrinology 16 1912-1919. (doi:10.1210/me.2002-0054)

Bischof JM, Stewart CL \& Wevrick R 2007 Inactivation of the mouse Magel2 gene results in growth abnormalities similar to Prader-Willi syndrome. Human Molecular Genetics 16 2713-2719. (doi:10.1093/ $\mathrm{hmg} / \mathrm{ddm} 225)$

Butler MG 2009 Genomic imprinting disorders in humans: a minireview. Journal of Assisted Reproduction and Genetics 26 477-486. (doi:10.1007/s10815-009-9353-3)

Cassidy SB \& Driscoll DJ 2009 Prader-Willi syndrome. European Journal of Human Genetics 17 3-13. (doi:10.1038/ejhg.2008.165)

Cattanach BM \& Beechey CV 2004 Genomic imprinting in the mouse: possible final analysis. In Genomic Imprinting. Frontiers in Molecular Biology, pp 118-145. Eds W Reik \& A Surani. Oxford: IRL Press at Oxford University Press.

Charalambous M, da Rocha ST \& Ferguson-Smith AC 2007 Genomic imprinting, growth control and the allocation of nutritional resources: consequences for postnatal life. Current Opinion in Endocrinology, Diabetes, and Obesity 14 3-12. (doi:10.1097/MED. 0b013e328013daa2)

Chen M, Gavrilova O, Liu J, Xie T, Deng C, Nguyen AT, Nackers LM, Lorenzo J, Shen L \& Weinstein LS 2005 Alternative Gnas gene products have opposite effects on glucose and lipid metabolism. PNAS 102 7386-7391. (doi:10.1073/pnas.0408268102)

Chen M, Wang J, Dickerson KE, Kelleher J, Xie T, Gupta D, Lai EW, Pacak K, Gavrilova O \& Weinstein LS 2009 Central nervous system imprinting of the $\mathrm{G}$ protein $\mathrm{G}(\mathrm{s})$ alpha and its role in metabolic regulation. Cell Metabolism 9 548-555. (doi:10.1016/j.cmet.2009.05. 004)

Chen M, Chen H, Nguyen A, Gupta D, Wang J, Lai EW, Pacak K, Gavrilova O, Quon MJ \& Weinstein LS 2010 G(s)alpha deficiency in adipose tissue leads to a lean phenotype with divergent effects on cold tolerance and diet-induced thermogenesis. Cell Metabolism 11 320-330. (doi:10.1016/j.cmet.2010.02.013)

Curley JP, Pinnock SB, Dickson SL, Thresher R, Miyoshi N, Surani MA \& Keverne EB 2005 Increased body fat in mice with a targeted mutation of the paternally expressed imprinted gene Peg3. FASEB Journal 19 1302-1304.

Davies SJ \& Hughes HE 1993 Imprinting in Albright's hereditary osteodystrophy. Journal of Medical Genetics 30 101-103. (doi:10.1136/ jmg.30.2.101)

Ding F, Li HH, Zhang S, Solomon NM, Camper SA, Cohen P \& Francke U 2008 SnoRNA Snord116 (Pwcr1/MBII-85) deletion causes growth deficiency and hyperphagia in mice. PLoS ONE 3 e1709. (doi:10.1371/journal.pone.0001709)

Ding F, Li HH, Li J, Myers RM \& Francke U 2010 Neonatal maternal deprivation response and developmental changes in gene expression revealed by hypothalamic gene expression profiling in mice. PLoS ONE 5 e9402. (doi:10.1371/journal.pone.0009402)

Ferguson-Smith AC \& Surani MA 2001 Imprinting and the epigenetic asymmetry between parental genomes. Science 293 1086-1089. (doi:10.1126/science.1064020)

Frontera M, Dickins B, Plagge A \& Kelsey G 2008 Imprinted genes, postnatal adaptations and enduring effects on energy homeostasis. Advances in Experimental Medicine and Biology 626 41-61. (doi:10. 1007/978-0-387-77576-0)

Gérard M, Hernandez L, Wevrick R \& Stewart CL 1999 Disruption of the mouse necdin gene results in early post-natal lethality. Nature Genetics 23 199-202. (doi:10.1038/13828)

Germain-Lee EL, Schwindinger W, Crane JL, Zewdu R, Zweifel LS, Wand G, Huso DL, Saji M, Ringel MD \& Levine MA 2005 A mouse model of Albright hereditary osteodystrophy generated by targeted disruption of exon 1 of the Gnas gene. Endocrinology 146 4697-4709. (doi:10.1210/en.2005-0681)

Gregg C, Zhang J, Weissbourd B, Luo S, Schroth GP, Haig D \& Dulac C $2010 a$ High-resolution analysis of parent-of-origin allelic expression in the mouse brain. Science 329 643-648. (doi:10.1126/science. 1190830)

Gregg C, Zhang J, Butler JE, Haig D \& Dulac C $2010 b$ Sex-specific parent-of-origin allelic expression in the mouse brain. Science 329 682-685. (doi:10.1126/science.1190831)

Haig D 2004 Genomic imprinting and kinship: how good is the evidence? Annual Review of Genetics 38 553-585. (doi:10.1146/ annurev.genet.37.110801.142741)

Hayward BE, Barlier A, Korbonits M, Grossman AB, Jacquet P, Enjalbert A \& Bonthron D 2001 Imprinting of the G(s)alpha gene GNAS1 in the pathogenesis of acromegaly. Journal of Clinical Investigation 107 R31-R36. (doi:10.1172/JCI11887)

Kaya AI, Ugur O, Oner SS, Bastepe M \& Onaran HO 2009 Coupling of beta2-adrenoceptors to XLalphas and Galphas: a new insight into ligand-induced $\mathrm{G}$ protein activation. Journal of Pharmacology and Experimental Therapeutics 329 350-359. (doi:10.1124/jpet.108. 149989)

Kehlenbach RH, Matthey J \& Huttner WB 1994 XLas is a new type of G protein. Nature 372 804-809. (doi:10.1038/372804a0)

Kelsey G 2010 Imprinting on chromosome 20: tissue-specific imprinting and imprinting mutations in the GNAS locus. American Journal of Medical Genetics. Part C, Seminars in Medical Genetics 154C 377-386. (doi:10.1002/ajmg.c.30271)

Keverne B 2009 Monoallelic gene expression and mammalian evolution. BioEssays 31 1318-1326. (doi:10.1002/bies.200900074)

Keverne EB, Fundele R, Narasimha M, Barton SC \& Surani MA 1996 Genomic imprinting and the differential roles of parental genomes in brain development. Brain Research. Developmental Brain Research 92 91-100. (doi:10.1016/0165-3806(95)00209-X)

Kohda T, Asai A, Kuroiwa Y, Kobayashi S, Aisaka K, Nagashima G, Yoshida MC, Kondo Y, Kagiyama N, Kirino T et al. 2001 Tumour suppressor activity of human imprinted gene PEG3 in a glioma cell line. Genes to Cells 6 237-247. (doi:10.1046/j.1365-2443.2001.00412.x)

Kozlov SV, Bogenpohl JW, Howell MP, Wevrick R, Panda S, Hogenesch JB, Muglia LJ, Van Gelder RN, Herzog ED \& Stewart CL 2007 The imprinted gene Magel2 regulates normal circadian output. Nature Genetics 39 1266-1272. (doi:10.1038/ng2114)

Kuroiwa Y, Kaneko-Ishino T, Kagitani F, Kohda T, Li LL, Tada M, Suzuki R, Yokoyama M, Shiroishi T, Wakana S et al. 1996 Peg3 imprinted gene on proximal chromosome 7 encodes for a zinc finger protein. Nature Genetics 12 186-190. (doi:10.1038/ng0296186)

Kuwajima T, Nishimura I \& Yoshikawa K 2006 Necdin promotes GABAergic neuron differentiation in cooperation with Dlx homeodomain proteins. Journal of Neuroscience 26 5383-5392. (doi:10.1523/JNEUROSCI.1262-06.2006)

Kuwako K, Hosokawa A, Nishimura I, Uetsuki T, Yamada M, Nada S, Okada M \& Yoshikawa K 2005 Disruption of the paternal necdin gene diminishes TrkA signaling for sensory neuron survival. Journal of Neuroscience 25 7090-7099. (doi:10.1523/JNEUROSCI. 2083-05.2005)

Lee S, Walker CL, Karten B, Kuny SL, Tennese AA, O'Neill MA \& Wevrick R 2005 Essential role for the Prader-Willi syndrome protein necdin in axonal outgrowth. Human Molecular Genetics 14 627-637. (doi:10.1093/hmg/ddi059)

Li L, Keverne EB, Aparicio SA, Ishino F, Barton SC \& Surani MA 1999 Regulation of maternal behavior and offspring growth by paternally expressed Peg3. Science 284 330-333. (doi:10.1126/science.284. $5412.330)$

Liu J, Litman D, Rosenberg MJ, Yu S, Biesecker LG \& Weinstein LS 2000 A GNAS1 imprinting defect in pseudohypoparathyroidism type IB. Journal of Clinical Investigation 106 1167-1174. (doi:10.1172/ JCI10431) 
Liu J, Erlichman B \& Weinstein LS 2003 The stimulatory G protein alpha-subunit Gs alpha is imprinted in human thyroid glands: implications for thyroid function in pseudohypoparathyroidism types 1A and 1B. Journal of Clinical Endocrinology and Metabolism 88 4336-4341. (doi:10.1210/jc.2003-030393)

Liu Z, Segawa H, Aydin C, Reyes M, Erben RG, Weinstein LS, Chen M, Marshansky V, Fröhlich LF \& Bastepe M 2011 Transgenic overexpression of the extra-large Gs $\alpha$ variant XL $\alpha$ s enhances Gs $\alpha$ mediated responses in the mouse renal proximal tubule in vivo. Endocrinology 152 1222-1233. (doi:10.1210/en.2010-1034)

Long DN, McGuire S, Levine MA, Weinstein LS \& Germain-Lee EL 2007 Body mass index differences in pseudohypoparathyroidism type la versus pseudopseudohypoparathyroidism may implicate paternal imprinting of Galpha(s) in the development of human obesity. Journal of Clinical Endocrinology and Metabolism 92 1073-1079. (doi:10.1210/jc.2006-1497)

Mantovani G, Ballare E, Giammona E, Beck-Peccoz P \& Spada A 2002 The gsalpha gene: predominant maternal origin of transcription in human thyroid gland and gonads. Journal of Clinical Endocrinology and Metabolism 87 4736-4740. (doi:10.1210/jc.2002-020183)

Mantovani G, Bondioni S, Locatelli M, Pedroni C, Lania AG, Ferrante E, Filopanti M, Beck-Peccoz P \& Spada A 2004 Biallelic expression of the Gsalpha gene in human bone and adipose tissue. Journal of Clinical Endocrinology and Metabolism 89 6316-6319. (doi:10.1210/jc. 2004-0558)

Miller JL, Goldstone AP, Couch JA, Shuster J, He G, Driscoll DJ, Liu Y \& Schmalfuss IM 2008 Pituitary abnormalities in Prader-Willi syndrome and early onset morbid obesity. American Journal of Medical Genetics. Part A 146A 570-577. (doi:10.1002/ajmg.a.31677)

Moore T \& Haig D 1991 Genomic imprinting in mammalian development: a parental tug-of-war. Trends in Genetics 7 45-49. (doi:10.1016/0168-9525(91)90230-N)

Morison IM, Ramsay JP \& Spencer HG 2005 A census of mammalian imprinting. Trends in Genetics 21 457-465. (doi:10.1016/j.tig.2005. 06.008)

Muscatelli F, Abrous DN, Massacrier A, Boccaccio I, Le Moal M, Cau P \& Cremer H 2000 Disruption of the mouse Necdin gene results in hypothalamic and behavioural alterations reminiscent of the human Prader-Willi syndrome. Human Molecular Genetics 9 3101-3110. (doi:10.1093/hmg/9.20.3101)

Relaix F, Wei XJ, Wu X \& Sassoon DA 1998 Peg3/Pw1 is an imprinted gene involved in the TNF-NFkappaB signal transduction pathway. Nature Genetics 18 287-291. (doi:10.1038/ng0398-287)

Sahoo T, del Gaudio D, German JR, Shinawi M, Peters SU, Person RE, Garnica A, Cheung SW \& Beaudet AL 2008 Prader-Willi phenotype caused by paternal deficiency for the HBII- $85 \mathrm{C} / \mathrm{D}$ box small nucleolar RNA cluster. Nature Genetics 40 719-721. (doi:10.1038/ng.158)

Schaller F, Watrin F, Sturny R, Massacrier A, Szepetowski P \& Muscatelli F 2010 A single postnatal injection of oxytocin rescues the lethal feeding behaviour in mouse newborns deficient for the imprinted Magel2 gene. Human Molecular Genetics 19 4895-4905. (doi:10. 1093/hmg/ddq424)

Schulz R, McCole RB, Woodfine K, Wood AJ, Chahal M, Monk D, Moore GE \& Oakey RJ 2009 Transcript- and tissue-specific imprinting of a tumour suppressor gene. Human Molecular Genetics 18 118-127. (doi:10.1093/hmg/ddn322)

de Smith AJ, Purmann C, Walters RG, Ellis RJ, Holder SE, Van Haelst MM, Brady AF, Fairbrother UL, Dattani M, Keogh JM et al. 2009 A deletion of the HBII-85 class of small nucleolar RNAs (snoRNAs) is associated with hyperphagia, obesity and hypogonadism. Human Molecular Genetics 18 3257-3265. (doi:10.1093/hmg/ddp263)
Smits G, Mungall AJ, Griffiths-Jones S, Smith P, Beury D, Matthews L, Rogers J, Pask AJ, Shaw G, VandeBerg JL et al. 2008 Conservation of the H19 noncoding RNA and H19-IGF2 imprinting mechanism in therians. Nature Genetics 40 971-976. (doi:10.1038/ng.168)

Swaab DF 1997 Prader-Willi syndrome and the hypothalamus. Acta Paediatrica Supplement 423 50-54.

Turan N, Katari S, Gerson LF, Chalian R, Foster MW, Gaughan JP, Coutifaris C \& Sapienza C 2010 Inter- and intra-individual variation in allele-specific DNA methylation and gene expression in children conceived using assisted reproductive technology. PLoS Genetics 6 e1001033. (doi:10.1371/journal.pgen.1001033)

Vrang N, Meyre D, Froguel P, Jelsing J, Tang-Christensen M, Vatin V, Mikkelsen JD, Thirstrup K, Larsen LK, Cullberg KB et al. 2010 The imprinted gene neuronatin is regulated by metabolic status and associated with obesity. Obesity 18 1289-1296. (doi:10.1038/oby. 2009.361)

Vu TH \& Hoffman AR 1994 Promoter-specific imprinting of the human insulin-like growth factor-II gene. Nature 371 714-717. (doi:10.1038/371714a0)

Weaver JR, Susiarjo M \& Bartolomei MS 2009 Imprinting and epigenetic changes in the early embryo. Mammalian Genome 20 532-543. (doi:10.1007/s00335-009-9225-2)

Weinstein LS 1998 Albright hereditary osteodystrophy, pseudohypoparathytoidism and Gs deficiency. In Contemporary Endocrinology: G Proteins, Receptors, Disease, pp 23-56. Ed AM Spiegel. Totowa, NJ: Humana Press, Inc.

Wilson LC, Oude Luttikhuis ME, Clayton PT, Fraser WD \& Trembath RC 1994 Parental origin of Gs alpha gene mutations in Albright's hereditary osteodystrophy. Journal of Medical Genetics 31 835-839. (doi:10.1136/jmg.31.11.835)

Wolf JB \& Hager R 2006 A maternal-offspring coadaptation theory for the evolution of genomic imprinting. PLoS Biology 4 e380. (doi:10. 1371/journal.pbio.0040380)

Xie T, Plagge A, Gavrilova O, Pack S, Jou W, Lai EW, Frontera M, Kelsey G \& Weinstein LS 2006 The alternative stimulatory G protein alphasubunit XLalphas is a critical regulator of energy and glucose metabolism and sympathetic nerve activity in adult mice. Journal of Biological Chemistry 281 18989-18999. (doi:10.1074/jbc. M511752200)

Yu S, Yu D, Lee E, Eckhaus M, Lee R, Corria Z, Accili D, Westphal H \& Weinstein LS 1998 Variable and tissue-specific hormone resistance in heterotrimeric Gs protein alpha-subunit (Gsalpha) knockout mice is due to tissue-specific imprinting of the gsalpha gene. PNAS 95 8715-8720. (doi:10.1073/pnas.95.15.8715)

Yu S, Gavrilova O, Chen H, Lee R, Liu J, Pacak K, Parlow AF, Quon MJ, Reitman ML \& Weinstein LS 2000 Paternal versus maternal transmission of a stimulatory G-protein alpha subunit knockout produces opposite effects on energy metabolism. Journal of Clinical Investigation 105 615-623. (doi:10.1172/JCI8437)

Zanella S, Watrin F, Mebarek S, Marly F, Roussel M, Gire C, Diene G, Tauber M, Muscatelli F \& Hilaire G 2008 Necdin plays a role in the serotonergic modulation of the mouse respiratory network: implication for Prader-Willi syndrome. Journal of Neuroscience $\mathbf{2 8}$ 1745-1755. (doi:10.1523/JNEUROSCI.4334-07.2008)

Received in final form 18 July 2011

Accepted 28 July 2011

Made available online as an Accepted Preprint 28 July 2011 